\title{
HISTORY AS A SCHOOL SUBJECT IN NATIONAL CURRICULA FOR ESTONIAN GENERAL COMPREHENSIVE SCHOOLS IN 1874-2015
}

\author{
Heiki Haljasorg \\ Tallinn University, Estonia \\ Urve Läänemets \\ Estonian academy of Music and Theatre, Estonia
}

\begin{abstract}
This study is focused on development of the content of history as a school subject in Estonian general comprehensive schools in 1874-2015. Selection of the content for learning has been influenced by the socio-political context and ideology in all times reflecting the officially recognized and accepted values. Theoretical analysis of selection of the content for history learning in Estonian general comprehensive schools is based on the works of de Tracy, Marx, Engels, Maritain, Althusser, Habermas, Žižek, Mannheim, Foucault, Popper, Gellner, de Beauvoir, Tyler, Taba, Goodson, Pinar, Kelly and Autio. All curriculum documents of the mentioned period have been analysed considering their aims, content of learning, time allotted for learning, and methods recommended in a thematic monograph. This article is focussed on aims and principles for selection of the content of history learning in Estonian general comprehensive schools, influenced by ideologies and contexts at different times.
\end{abstract}

Keywords: national curriculum, history syllabus, ideology, values, content of learning, organisation of the content.

\section{Introduction}

George Orwell in his book 1984 wrote: „Who controls the past”, ran the party slogan, ,controls the future: who controls the present controls the past”. This quote aptly describes the content and ideological character of history, as a school subject in general comprehensive schools meant for educating all the population. History as a form of specific knowledge has been generally acknowledged as an opportunity to learn from the experience of predecessors of different times and locations. The problem, what to choose for learning, has persisted up to present days and no specified criteria for selection of its content have been established. However, in Estonia research on development of the content for learning languages and their presentation in national curricula (NC) has been carried out, but that of history learning has not been the object of research so far. This article attempts to shed some light on development of history as a school subject in Estonian general comprehensive schools in 1874 - 
2015 and find out how ruling ideologies in society have influenced history learning in different times.

The method used for research is document analysis (qualitative content analysis) covering all available documents characterising the mentioned period in official NC, programs and syllabi considering the goals of learning, the content of studies, the time allotted and recommended methods for teachers.

\section{Theoretical background}

The term history as a subject for learning can be traced back to its origin in

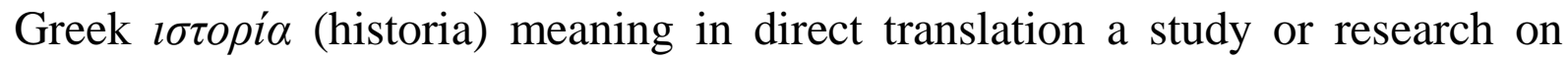
different sources of information. Written documents, books, objects, oral records, etc. are used for reconstruction and comprehension of past events and developments using relevant, often alternative methods (Karjahärm, 2004, p. 124-125). This is the field for historians, but for educating people about the experience of the past, meaningful and implementable for the present and probably future, a subject for schooling was developed. However, comprehension of the past and its values worth being transferred to new generations is never created by scientists only, more often values are specified and explained/influenced by laws in society, by literature, educational systems, home environments, media and nowadays especially by the Internet. All the mentioned and more factors can be specified as tools of ideology, specifying the values and creating a context for an individual for comprehension of values as foundations for his/her activities, usually based on informed decision-making.

The term ideology also comes from Greek iśz $\alpha$, meaning form, pattern,

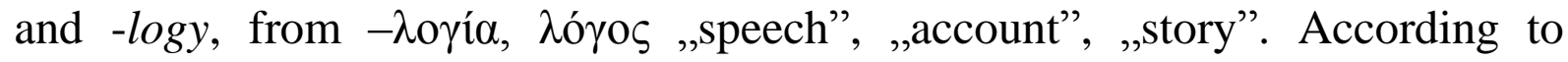
Blackburn, ideology is any wide-ranging system of beliefs, ways of thought, and categories that provide the foundation of programmes of political and social action (Blackburn, 2008, p. 178). Among political ideologies there are, e.g. classical liberalism, conservatism, reform liberalism, democratic socialism, Marxism, anarchism, libertarianism, fundamentalism, feminism, environmentalism, and pacifism (McCullough, 2010, p. 1), which greatly influence social life and education in particular. For selection of the content in curricula Eisner distinguishes between the following ideologies: religious orthodox, rational humanism, progressivism, critical theory, re-conceptualism and cognitive pluralism (Eisner, 1992). All ideologies manifest recognised and accepted values in society in a particular time, often specified as value education.

Value education is by which people give values to others. (Powney et al., 1995 , p. vii). The two main methods of value education are values clarification or rational education of ethics (discussions about values; based primarily on 
deontological ethics by Immanuel Kant) and character education, or education of individual nature (development of good characteristic traits and their reinforcement; based primarily on ethics of virtues by Aristotle) (Põder et al., 2009, p. 12).

However, due to specific values in diverse cultures, and social groups in power, history writing as well as comprehension and interpretation of a particular historical event or phenomenon can be vastly different. Therefore several researches have denied the possibility of writing any objective history. All histories have been written from the position of some influential individual or social group, representing their comprehension of events.

Already Tacitus in his Annals has highlighted this evergreen principle of history writing as follows: The histories of Tiberius, Gaius, Claudius, and Nero, while they were in power, were falsified through terror, and after their death were written under the irritation of a recent hatred. Hence my purpose is to relate a few facts about Augustus - more particularly his last acts, then the reign of Tiberius, and all which follows, without either bitterness or partiality (sine ira et studio), from any motives to which I am far removed." (Tacitus, 2015) Consequently, it has to be admitted that history has been "rewritten" according to manifested ideologies ever since, which in turn has greatly influenced the selection of what is considered valuable to be remembered and to learn from. The most influential theorists for ideologies influencing history learning in Estonian general comprehensive schools since the post-WWII period are Karl Marx, Friedrich Engels, Jacques Maritain, Louis Althusser, Michel Foucault, to name just a few, but also considering organisation of general education at large in the $20^{\text {th }}$ and $21^{\text {st }}$ centuries.

\section{What has been the message of the mentioned ideologists for comprehension of history?}

Karl Marx and Friedrich Engels declare in The German Ideology (Die Deutsche Ideologie) that the ideas of the ruling class are in every epoch the ruling ideas (Marx \& Engels, 2015). Their systematic theses of dialectical materialism, of all subjected to change, class struggle, history and importance of economic factors in politics have exercised enormous influence on later thinkers and political leaders as well as on education in the period of Soviets in Estonia in 1940-1991.

Jacques Maritain, however, in his work The Philosopher in Society, recommends contemplation as an approach: If philosophy is one of the forces which contribute to the movement of history and the changes that occur in the world, it is because philosophy, in its primary task, which is the metaphysical penetration of being, is intent only on discerning and contemplating what is the 
Heiki Haljasorg, Urve Läänemets. History as a School Subject in National Curricula for Estonian General Comprehensive Schools in 1874-2015

truth of certain matters which have importance in themselves and for themselves, independently of what happens in the world, and which, precisely for that reason, exert an essential influence on the world." (Maritain, 1961, p. 8).

Louis Althusser has also analysed ideologies in the context of education saying in his essay Idéologie et appareils idéologiques d'État the following: I ask the pardon of those teachers who, in dreadful conditions, attempt to turn the few weapons they can find in the history and learning they 'teach' against the ideology, the system and the practices in which they are trapped. They are a kind of hero. But they are rare and how many (the majority) do not even begin to suspect the 'work' the system (which is bigger than they are and crushes them) forces them to do, or worse, put all their heart and ingenuity into performing it with the most advanced awareness (the famous new methods!) " (Althusser 1970)

Michel Foucault in his book Discipline and Punish analyses the relations between power, knowledge and ideologies and how forms of human subjectivity are constructed by specific institutions and practices (Foucault, 2002 \& Foucault, 1993), which became especially popular since regained independence in 1991. Educational documents of 1874-2015 demonstrate interesting developments in organising general education and history learning as part of it in different political and social contexts.

Accordingly, the history learning in different periods has been focussed on different developments, events and/or historic personalities in history. The content of history, or the knowledge considered necessary and valuable for acquisition has been selected according to power relations (geopolitical aspirations and wars), class struggles (revolutions and the role of the working class), or national, cultural and scientific developments and the role of outstanding people. The content presented in the analysed NC clearly reflects these criteria.

\section{Research results: a short overview of history learning in Estonian general comprehensive schools at different times}

Analyses of collected materials have revealed that the school subject called histooria or stories about things that have happened can be traced back to 1874, and since 1880 as the book by J. Bergmann, titled as General History appeared, the term history has been generally used. Understandably, there was no NC as an official document prescribing the standard of national education provided in Estonian in those days, as Estonia was part of the Russian Empire and schools worked according to the plans of Russian Empire specified for this region. The curriculum for primary schools of 1917, compiled by Tallinn Teachers' Union 
with the aim to facilitate teachers work, did not contain history as a school subject.

The first official NC for Estonian schools can be found from 1919 (after the statehood was established in 1918). Its structure included an introductory general part manifesting general goals of schooling, subject syllabi with specified aims and the number of lessons and the content of learning (themes). All subsequent NC have followed these elements and added sometimes lists of school textbooks and other study aids, or chapters recommending methods to be used in the lessons. In recent NC there are also parts characterising physical learning environments and assessment.

Next, we will focus on the specification of the influential ideologies and selection of the content for history learning in Estonian NC. According to their relationship with the socio-political contexts the analysis is presented in three different periods: 1918-1940 (the first period of Republic of Estonia), 19401991 (the period of occupations) and 1991-2015 (the period of regained independence). Detailed data will be available in the forthcoming monograph.

\section{History learning in 1918-1940}

This period can be called the period of establishment of the nation state and national education system, which aspired towards development of educated population with knowledge of historical heritage of mankind considered valuable and accordingly useful for everybody in their lives. The ideology, manifested by politicians of those days was clearly national in character and history as school subject provided first of all knowledge from the Estonian history as well as that of some leading European countries, and of Ancient times. Lists of historical heroes were specified as well as military events and traditional periods of history. Understandably, there were no educational sciences available to support curriculum development of those days.

The following NC of 1921 was quite specific in its aims: pupils of primary schools were expected to acquire knowledge from different fields and understand the bridge between past and present, which would help them understand current developments and that different cultures influence each other in historical circumstances (NC, 1921, p. 49). Moreover, it is also clearly manifested that specific party and politics related tendencies must be kept outside schools (ibid: p. 50). The content selected for learning was wider and more focussed on culture.

The NC of 1928 specified a new aim- educating loyal citizens with wider cultural horizons, developed by knowledge about history of other nations and their outstanding people of different times (NC, 1928, p. 5), which is already 
clearly politically coloured. The idea of integration of history with other school subjects is also mentioned for the first time.

The NC for primary schools of 1937 repeats basically the same aims and the history as a school subject also contains elementary social studies. The NC for upper secondary schools of 1930 specifies 4 aims: to comprehend present via past, develop thinking skills on history, love towards Estonia as fatherland and comprehension of international solidarity (NC, 1930). The content was widened by knowledge of society as a state system.

United curricula for all school levels of 1938 offered the same specification of the content with some amendments for gymnasia (NC, 1938, p. 46). Curriculum documents of this period show development of ideologies from national towards international with increasing amount of study themes and topics, concepts and lists of historic personalities from different fields of human life, from traditional military heroes to inventors and those creative in different fields of culture. The content of history learning followed the development of the Estonian state, its national and international aspirations.

\section{History learning in 1940-1991}

History learning in the mentioned period was coloured by change of powers - from Soviets 1940 to German in 1941, and back to Soviets from 1945 until 1991, with clearly changing ideologies following the events of the WWII as well as social and economic developments in the SU.

History learning in 1940 had to follow the principles of Marxism Leninism, but there was no time for its implementation. The curriculum of 1943 does not specify any aims for learning history, there is only the list of themes to be studied (Curriculum, 1943, p. 27-33). All post-WWII syllabi were called programs for learning history and issued as separate documents with specific recommendations for teachers. According to the new Soviet (Marxist - Leninist) ideology, the program of 1948 manifested totally new approaches towards the traditional periods of history, historic events and personalities from the point of class struggle and hegemony of the working people.

The task to teach correct political views (Pr, 1948, p. 9), development of patriotism and hatred towards fiends of the homeland were clearly expressed. The role of Russia, its history, culture and achievements were highlighted. Europe-centrism had to be avoided (ibid, p. 38) religions were shown as tools in the hands of exploiters, etc. The concept of fair and unfair wars was introduced, the role of the Communist Party had to be understood in the correct way and the peace aspirations of the SU were highlighted. The program of 1952 was not so specific any more, but ideological-political education of students was brought to the foreground. 
The programs of 1952, 1954 and 1955 were still coloured by Stalinist ideology, but the program of 1956 was already critical about Stalin cult, and also admitted the coexistence of capitalist and socialist economic systems. The programs for learning history were updated every few years (those of 1957, $1958,1960,1963)$ and those clearly followed the developments on the international arena and how the SU has acted. The Marxist ideology became adapted to changing realities. The programs of 1964, 1965 and 1966 manifested the goal of educating the Soviet nation able to combat imperialist ideology ( $\mathrm{Pr}$, 1964 , p. 4), and history as a school subject was first expected to contribute to development of personality.

The following program of 1970 was a real milestone as it contained several topics on Estonia besides themes reflecting communist ideology and traditional history. There was a special course on national culture and history; for the first time an optional course, integrating Estonian history and literature, was introduced, and a list, recommending films and literary works on historical themes was recommended with the aim to increase students' motivation for learning history. Events of 1956 have been mentioned, but not those in Prague of 1968.

Programs of 1972 and 1974 were still manifesting communist ideals, based on scientifically sound and rich knowledge with implementation of films, extracurricular activities and TV supporting traditional history lessons.

The programs of 1978 and 1982 highlighted already dialectic-materialist ideology and aspirations towards comprehension of people as agents of history. Towards the end of the Soviet era, in the programs of 1984 and 1986 more attention was paid to developments in other socialist countries; importance of wide factual knowledge and ethics was stressed, already reflecting some traits of glasnost and perestroika.

\section{History learning in 1991-2015}

Regained independence in 1991 meant a great change towards democratization of society and introduction of several new, mainly liberal ideologies. It also meant great changes in learning history and civics. Examples and ideas mainly from Nordic countries, the USA and UK were studied and implemented at different levels. In 1992 and 1993 the draft versions of curricula for compulsory and upper secondary general comprehensive school were developed in the Estonian Education Centre, however the first new official curriculum for general comprehensive schools was adopted in 1996. In 2002 a new introductory part was added to the curriculum of 1996, and the most recent curricula for compulsory schools and gymnasia were adopted in 2011. Different new ideologies have been implemented, which allow schools to develop their 
own school curricula and use optional subjects, some of which can also be used for learning some specific courses of history. The content has been specified by themes for compulsory school and by courses for gymnasia. Accordingly, the number of compulsory lessons has decreased. The content has become somewhat unbalanced and eclectic, as in 1997-2013 history was also the school subject in which National Examinations were organized. Compulsory courses in the curriculum specify particular periods, including history of Estonia, but schools are expected to develop their own and more specific content for their school curricula and syllabi.

\section{Conclusion}

The aims and content of history learning in every analysed period have had its clearly distinguishable character following the ideology of its time. When the syllabi of the first period followed the conservative-nationalist ideology, the history programs of the Soviet period were coloured by Marxist ideology. The liberal and new-liberal ideologies are reflected in the curricula and syllabi of the new Estonia. Environmentalism, feminism, criticism of ethnocentrism and presentism as ideologies are currently being discussed, which may have further impact on learning history in future. However, traditional European and humanist values have recently gained ground. It can be concluded with the wellknown quote by Estonian poet Juhan Liiv: Who does not remember the past, is living, but without future. Consequently, we still need history for numerous reasons - for our identity building and cohesion in society, but also for sustainability of the culture and statehood.

\section{References}

Althusser, Louis. (1971). Ideology and Ideological State Apparatuses (Notes towards an Investigation). In: "Lenin and Philosophy" and Other Essays. New York: Monthly Review Press - https://www.marxists.org/reference/archive/althusser/1970/ ideology.htm (Retrieved 06/01/2016).

Bergmann, J. (1879). Üleüldine ajalugu: 1. jagu: Wana aeg / Kolmes jaus koolidelle ning igale teaduse nõudjale kirja pannud. Tartu: Schnakenburg.

Blackburn, S. (2008). Dictionary of Philosophy. Oxford: Oxford University Press.

Eisner, E. W. (1992). Curriculum Ideologies. - P. W. Jackson. Handbook of Research on Curriculum. New York: Macmillan.

Foucault, M. (1993). Surveiller et punir: Naissance de la prison. Paris: Gallimard.

Foucault, M. (2002). The Archaeology of Knowledge. Roudledge: Roudledge Classics.

Karjahärm, T. (2004). Ajaloolase käsiraamat. Tallinn: Argo.

McCullough, H. B. (2010). Political ideologies. Oxford: Oxford Unversity Press.

Maritain, Jacques. (1961). On the Use of Philosophy. Three Essays. Princeton: Princeton University Press. 
Marx, K., \& Engels. (1845). The German Ideology. - https://www.marxists.org/archive/marx/ works/1845/german-ideology/ch01b.htm (Retrieved 06/01/2016)

Orwell, G. (1983). 1984. New York, Scarborough: New Amer. Lib.

Powney, J., Cullen, M. A., Schlapp, U., Johnstone, M., \& Munn, P. (1995). Understanding Values Education in the Primary School. York: Reports Express.

Põder, M., Sutrop, M., \& Valk, P. (2009). Väärtused, iseloom ja kool: Väärtuskasvatuse lugemik. (Values, character and schooling: reader on value education., in Estonian) Tartu: Eesti Keele Sihtasutus.

Tacitus. (1876). Annals. Retrieved 06/01/2016 from http://www.romansonline.com/Src_ Frame.asp?DocID=Ann_Bk01_01.

\section{Documents:}

1. Curriculum of 1917

2. Curriculum of 1943

3. National Curriculum of 1919

4. National Curriculum of 1921

5. National Curriculum of 1928

6. National Curriculum of 1930

7. National Curriculum of 1937

8. National Curriculum of 1938

9. National Curriculum of 1996

10. National Curriculum of 1997

11. National Curriculum of 2002

12. National Curriculum of 2010

13. National Curriculum of 2011

14. Plan for studies at schools in Estonia of 1874

15. The history programs of 1948

16. The history programs of 1952

17. The history programs of 1954

18. The history programs of 1955

19. The history programs of 1956

20. The history programs of 1957

21. The history programs of 1958

22. The history programs of 1960

23. The history programs of 1963

24. The history programs of 1964

25. The history programs of 1965

26. The history programs of 1966

27. The history programs of 1970

28. The history programs of 1972

29. The history programs of 1974

30. The history programs of 1972

31. The history programs of 1974

32. The history programs of 1978

33. The history programs of 1982

34. The history programs of 1984

35. The history programs of 1986 